\title{
POST HARVEST BACTERIAL LOAD IN THE GUT OF OMPOK PABDA (HAMILTON, 1822) FROM TWO FISH MARKETS OF BRAHMANBARIA
}

\author{
Tanjila Akter and Gawsia Wahidunnessa Chowdhury*
}

Department of Zoology, University of Dhaka, Dhaka-1000, Bangladesh

\begin{abstract}
This study was conducted to enumerate the post harvest bacterial load in the gut of captured and cultured Ompok pabda by spread plate method using different selective culture media. The bateriological parameters, such as total viable bacterial counts (TVBC), total coliform counts (TCC), total fecal coliform counts (E. coli), pathogenic bacteria Salmonella spp, Shigella spp. and Vibrio cholerae were determined. Highest bacterial load was found in the month of July and lowest in January. The quantitative and qualitative aspects of gut microbes showed that TVBC of captured O. pabda were found $9.2 \times 10^{6}, 7.0 \times 10^{7}, 9.5 \times$ $10^{6} \mathrm{cfu} / \mathrm{g}$ and that of cultured fish were $1.56 \times 10^{7}, 7.2 \times 10^{7}$ and $2.24 \times 10^{7} \mathrm{cfu} / \mathrm{g}$ during pre-monsoon, monsooon and post-monsoon, respectively. The bacteriological quality of fish from both captured and cultured sources did not comply with ICMSF standard. Pathogenic bacteria E. coli, Salmonella spp., Shigella spp. and Vibrio cholerae were also detected from both captured and cultured $O$. pabda. The findings of this study indicated that the fish collected from the local fish markets were contaminated with different pathogenic bacteria that reflect the unhygienic conditions of the markets.
\end{abstract}

Key words: Microbial load, Ompok pabda, captured and cultured, fish quality, seasonal variation

\section{INTRODUCTION}

National economy of Bangladesh has been blessed with the contribution of the fisheries sector. Currently Bangladesh has been ranked as the third in inland open water capture production and fifth in world aquaculture production with a total production of 42.77 lakh MT in financial year 2017-18, where contribution of aquaculture is recorded as $56.24 \%$ of the total fish production (DoF 2018). A total of 253 freshwater fish species have been recorded from Bangladesh (IUCN 2015), which belong to 55 families. Of these over 150 species have been classified as 'small indigenous species' (Kostori et al. 2011). This 'small indigenous species' group of fish played important role as source of protein, calcium and minerals to the daily diet and was identified as a substantial income source for the small scale fishermen (Islam 2011).

Disease outbreak due to different microbes and others parasites is one of the major problems that affect the quality of the aquaculture production (Tuan et al. 2013) although some microbes are beneficial for them. For specialized bacteria

*Author for correspondence: <gawsia@gmail.com/gawsia@du.ac.bd>.

(c)2019 Zoological Society of Bangladesh DOI: https://doi.org/10.3329/bjz.v47i2.4433 
that are beneficial for their dietary life style, the host provides a niche; in return intestinal microbes provide exogenous nutrients and extracellular enzymes, fatty acids and vitamins which are not available to the host (Dehler et al. 2017). They also contribute to the digestion of complex food materials. According to Austin (2006) an established community of microbes is able to reduce the growth and proliferation of pathogenic bacteria and play a key role in disease control.

Due to their soft tissue and status of the aquatic habitats, fishes are susceptible to microbial contamination which degrades the quality of fish (Francoise 2010). Guality of a large amount of fish deteriorated every year because of the growth and activity of pathogenic bacteria (Noor et al. 2013). The spoiling activities by specific bacteria mainly depend on fish type and chemical composition of fish, feeding habits, the area from where the fish has been harvested and also the types of fishing gear used during harvesting (Francoise 2010). However, fish can also be infected from outside environment during careless handing of the fish species, its packing, storing and cutting but major external sources of bacterial contamination are ice and salt. Pal et al. (2016) reported that crushed ice usually carried heavy bacterial loads and responsible for the bacterial diseases of fish.

Pathogenic bacteria such as Vibrio spp. Shigella spp., Salmonella spp., Streptococci spp., coliforms, Clostridium spp. and Staphylococci spp. which enter into the fish from their habitat or during fish transportation and storage have been reported to affect fish health (Elham 2017). Food borne disease like diarrhoea, typhoid, fever, salmonellosis, shigellosis, cholera and even some neurological diseases reported to be caused by the consumption of microbiologically spoiled fish (Snowdon et al. 1989). It is recorded that $80 \%$ of all illnesses are associated with poor microbial quality of which the major diseases are actual cases of food borne diseases (Okonko et al. 2008). According to Begum et al. (2015), uncontrolled and irregular use of antibacterial agents in aquaculture systems is also responsible for the occurrence of the multiple antibiotic resistance traits among the fish pathogens.

Ompok pabda, popularly known as Butter catfish (locally known as Modhupabda), is a small indigenous catfish belongs to the family Siluridae of the order Siluriformes (Banik et al. 2012). This fish species is considered as one of the most delicious, nutritious and demanding to people of Bangladesh. However, improper handling, poor icing and bad trading practices have been reported as the factors that negatively impacted the fish quality and considering the reasons, some fish species are unable to reach the consumer demand (Duarte et al. 2014). Also the water quality of both naturally flowing water and culture pond is different, bacterial loads in two different systems may vary and 
needs to be determined. Therefore, this study was attempted to enumerate the bacterial load and to isolate the pathogenic bactera in the gut of captured and cultured Ompok pabda collected in three seasons from two fish markets.

\section{MATERIAL AND METHODS}

Collection of fish samples: From two different selected sources. Captured fish were collected from 'Kawtoli Bazar' $\left(23^{\circ} .9563^{\prime} \mathrm{N}, 91^{\circ} .1140^{\prime} \mathrm{E}\right)$, very close to the freshly caught fish landing site known as 'Kawtoli Nowka Ghat' and cultured fish from 'Anondo Bazar' $\left(23^{\circ} .9760\right.$ 'N,91 $\left.{ }^{\circ} .1124^{\prime} \mathrm{E}\right)$ where fish were brought from nearby fish farms from Brahmanbaria district, Bangladesh (Fig. 1). Fish specimens were collected at the early morning during three seasons - premonsoon (January-April), monsoon (May-August) and post-monsoon (September to December) from July 2018 to June 2019. Five specimens of the study species were collected at each season for analysis.

\section{Map of Sampling sites}

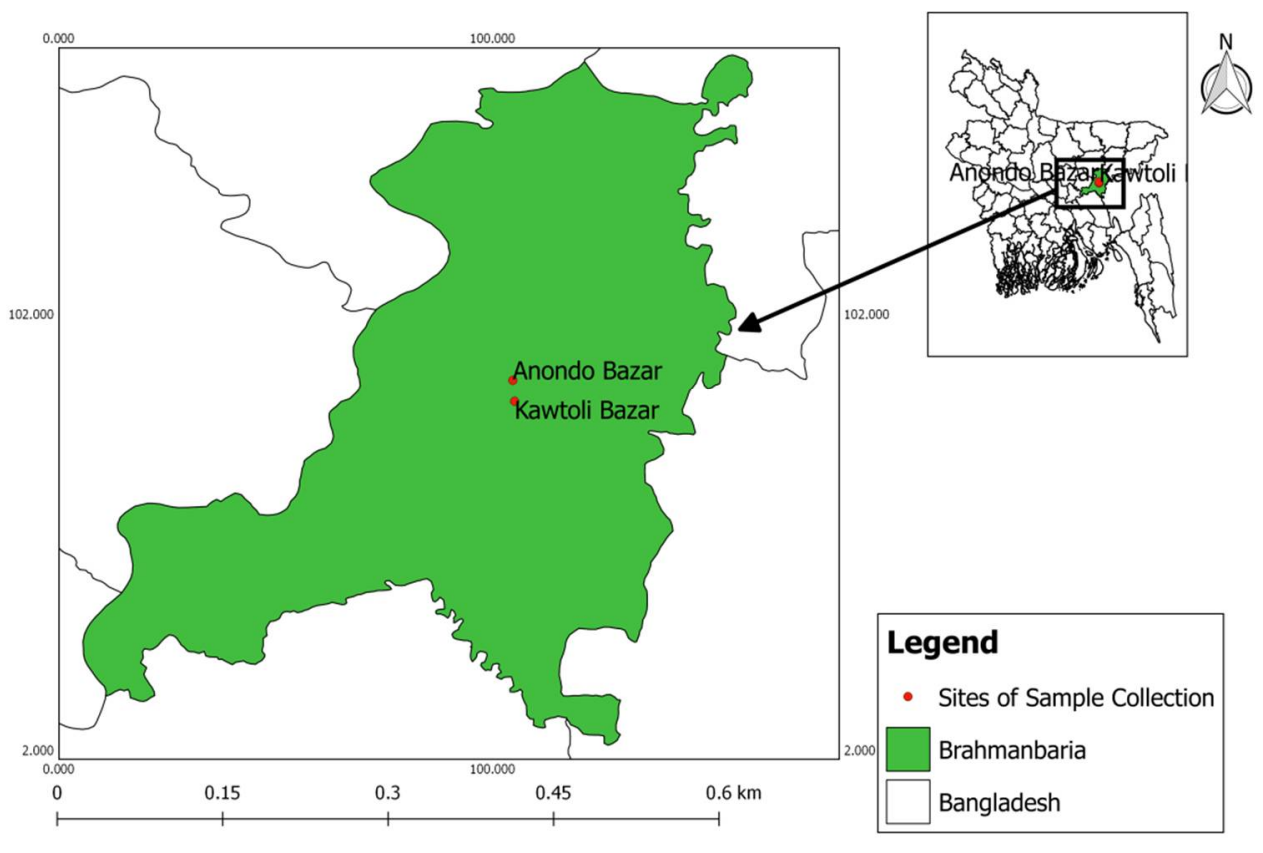

Fig. 1. Ompok pabda collection sites.

Sample preservation: Collected fish specimens were preserved in sterile polyethylene bags which were installed with sufficient ice-block to keep the temperature between 4 and $6^{\circ} \mathrm{C}$. Then transported to Dhaka and kept in refrigerator for short time preservation. On the same day, the collected samples 
were carried to the microbiological research laboratory at the Department of Microbiology, University of Dhaka, for further analysis.

Preparation of sample: First, $10 \mathrm{~g}$ of fish sample was taken aseptically by sterile knife from gut of fish and measured by weighing balance. Then the sample was mixed homogeneously with $90 \mathrm{ml}$ of saline water in a stomacher lab blander. The sample was shaken properly for homogeneous suspension. Then the sample was transferred to conical flask and sealed. The homogenate solution gave $10^{-1}$ dilution which was called original sample stock. Later, 10 folds serial dilutions (1 : 10) was prepared up to $10^{-5}$ for each fish sample following International Standard Organization (ISO 1995).

Microbiological analysis: Bacteriological parameters for the study fish samples were - quantitative and qualitative analysis of total viable bacterial count (TVBC), total coliform counts (TCC), total fecal coliform counts (TFC), Salmonella spp., Shigella spp. and Vibrio cholerae. Different selective culture media were used for growth, isolation and identification of different bacteria. Nutrient agar media were used for TVBC. For coliform bacteria MacConkey agar medium was used where typical pinkish and centrally red colonies were considered to identify total coliform. For the growth of fecal coliform (E. coli), $\mathrm{mFC}$ agar medium was used in which blue colonies were counted as TFC ( $E$. coli). XLD agar medium was used for the growth of Salmonella spp. and Shigella spp. In XLD medium small sized black colored colonies were counted as Salmonella spp. and red colonies were counted as Shigella spp. Vibrio cholerae was isolated by using TCBS media in which $V$. cholerae showed small size yellowish colonies.

Microbial count: Microbiological analysis was carried out according to the Bacteriological Analytical Manual (2018). Quantitative analysis of bacterial load was made by standard plate count (SPC) techniques and $1 \mathrm{ml}$ of the diluted solution $\left(10^{-2}\right.$ to $\left.10^{-5}\right)$ from each sample was taken and inoculated on each plate containing selective culture media. Solution was spread through glass spreader. All plates were incubated at a definite temperature for $24 \mathrm{hrs}$ before colony isolation and enumeration. The counting was calculated by using the following formula and expressed as $\mathrm{cfu} / \mathrm{g}$.

$\mathrm{cfu} / \mathrm{g}=$ No. of colonies on Petri dish $\times$ dilution factor $\times$ volume of total sample solution wt. of fish samples (g)

Statistical analysis and interpretation were done by using computer software: Microsoft Excel. 


\section{RESULTS AND DISCUSSION}

Bacterial loads were enumerated from gut of the fish samples collected from two different sources in three seasons. Freshly captured Ompok pabda from the river was collected from Kawtoli Bazar whereas the cultured O. pabda from fish farms was collected from Anondo Bazar to compare the seasonal variation of bacterial loads. The mean of total bacterial load was calculated as mean log $\mathrm{cfu} / \mathrm{g} \pm \mathrm{Sd}$. Mean of the total viable bacterial count (TVBC), total coliform count (TCC), fecal coliform (E. coli) count (FCC), Salmonella spp., Shigella spp. and Vibrio cholerae were enumerated and presented in Figs 2 and 3.

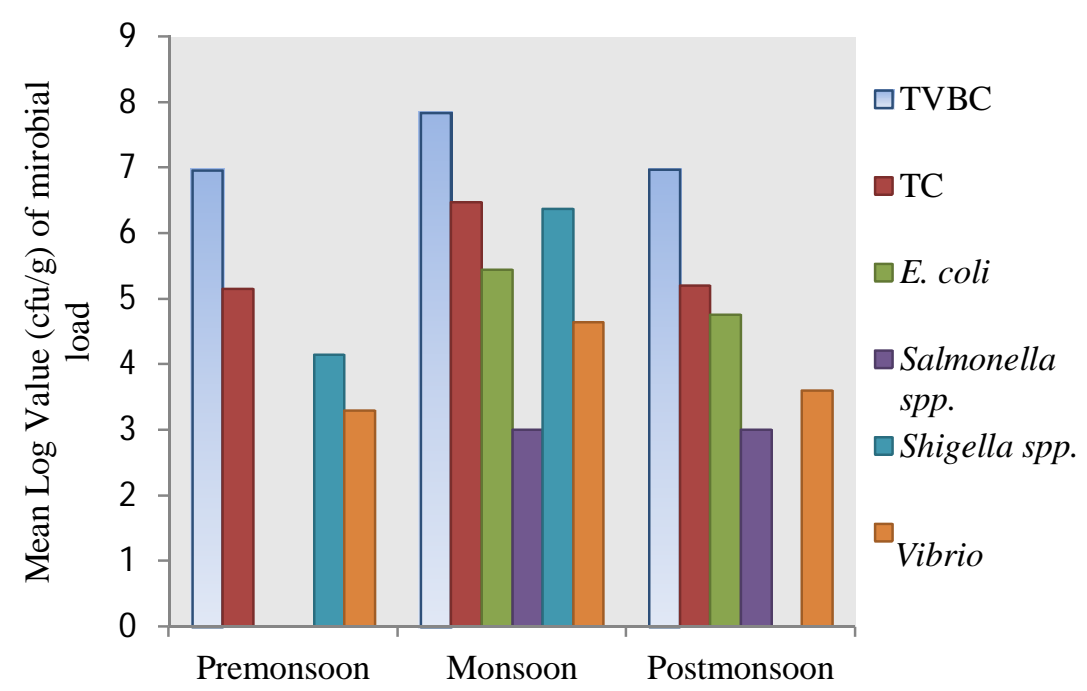

Fig. 2. Comparative analysis of microbial load (log value) in captured fish analyzed in different seasons.

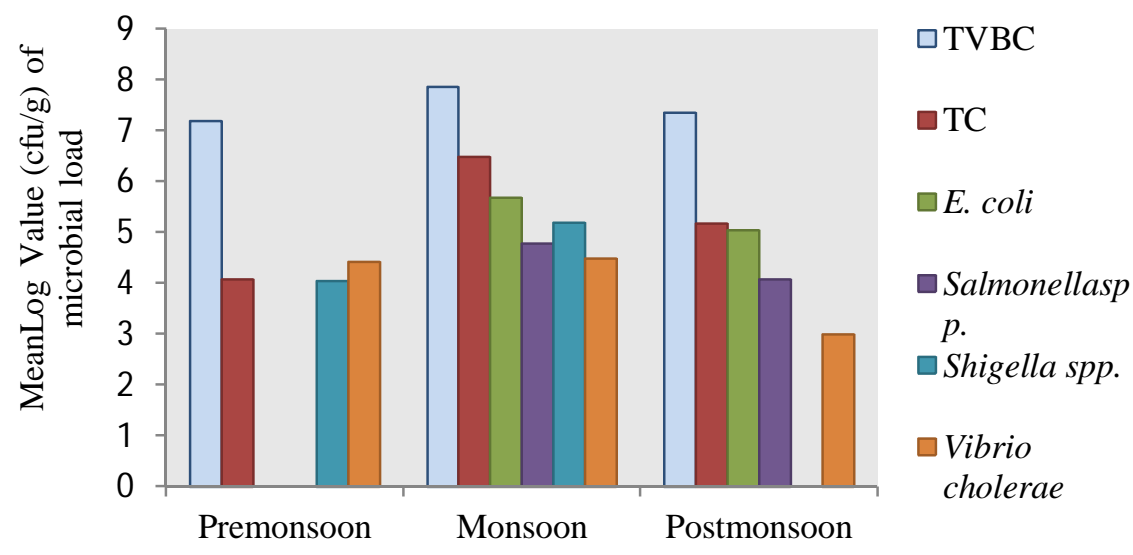

Fig. 3. Comparative analysis of microbial load (mean log value) in cultured fish analyzed in different seasons. 
The mean log values of TVBC determined for both captured and cultured fish were $7.261 \pm 0.256$ and $7.467 \pm 0.120$. The mean log value of total coliform (TC) for captured fish was $5.612 \pm 0.562$ and for cultured fish it was $5.244 \pm 0.1 .441$. The mean log value of fecal coliform (E. coli)) for captured fish was $5.102 \pm 0.239$ and for cultured fish was $5.361 \pm 0.205$. The mean log value of Salmonella spp. for captured fish it was $3 \pm 0$ and for cultured it fish was $4.426 \pm 0.244$. The mean log value of Shigella spp. for captured fish it was $4.763 \pm 0.761$ and for cultured fish it was $4.617 \pm 0.664$ (Figs 2 and 3).

This study enumerated bacteria from the gut of the fish species. Maya et al. (1995) also identified the microorganisms in the digestive system of fish and also reported that living fish usually harbor some common Gram negative facultative anaerobic bacteria in their gut throughout the year. Bacteria present in the gut region are not always harmful, some of them are beneficial to their fish host, and play a significant role in the digestion, metabolism and nutrition of the fish.

However, high bacterial load decreases the quality of fish quickly which spoil the food product and is responsible for different microbial diseases, which was also reported by Hossain et al. (1999). They found that the bacterial strain isolated from intestine are found positive in proteinase test, catalase activities. This property indicated that most of the bacteria are associated with spoilage activities thus contribute to the quality deterioration. Contaminated food by different pathogens may harbor virulence genes which are responsible for disease outbreak (Noor et al. 2013).

In present study, bacterial load in captured and cultured fish was found highest in the monsoon season and lowest in pre-monsoon (Figs 1 and 2). This may be due to slightly higher temperature in monsoon than the other seasons. Duarte et al. (2014) aiso reported that the bacterial population grow higher during monsoon due to availability of more nutrient and favorable temperature in water during monsoon. Hossain et al. (1999) also found highest bacterial load in the monsoon (July) and lowest in pre-monsoon (January) which supports the findings of this study.

FAO (1979) described that Salmonella spp., Shigella spp., Vibrio cholerae and other enteric pathogens may not be found as these microorganisms are not the normal flora of the fishes or their environment. According to the guideline of ICMSF (1986) acceptable limit of total viable bacterial count for fresh and frozen fish is $5 \times 10^{5} \mathrm{cfu} / \mathrm{g}$ for good quality. TVBC count above $5 \times 10^{7} \mathrm{cfu} / \mathrm{g}$ and fecal coliform count above $5 \times 10^{2} \mathrm{cfu} / \mathrm{g}$ are unacceptable and Salmonella spp. and Vibrio cholerae should be absent. According to FSA (2001) for the microbiological Quality of some ready to eat food acceptable limit for 
Enterobacteriaceae range from $10^{2}$ to $10^{4} \mathrm{cfu} / \mathrm{g}$, for E. coli range from 20 to 100 cfu/g whereas Salmonella spp., Shigella spp. and Vibrio cholerae may not be detected in $25 \mathrm{~g}$.

In this study, the mean log values of TVBC for captured and cultured fish were found $7.26 \pm 0.256$ and $7.467 \pm 0.12$ (Fig. 3). Leiva et al. (2017) also observed the similar result in their study. Their findings were $5.14 \pm 0.71$ (mean value) for wild flounder (WF) and $5.49 \pm 0.59$ (mean value) for aquaculture flounder (AF). All the samples in this study contained higher bacterial load which did not comply with the acceptable limit of ICMSF (1986). As they contained higher bacterial load so the bacteriological conditions for both captured and cultured fish were not so good. The TCC and fecal coliform (E. coli) of both captured and cultured fish in this study did not comply with the acceptable limits of FSAI (2001). The pathogenic bacteria E. coli, Salmonella spp., Shigella spp. and Vibrio Cholerae were detected during this experiment (Figs 1, 2 and 3). But ICMSF (1986) showed zero tolerance of Salmonella spp. and Vibrio Cholerae in the fish and fish product. Presence of pathogenic bacteria in fish can cause intestinal disease like cholera, diarrhea, salmonelosis and shigelosis to the consumers. The pollution of aquatic environment by different external sources can be considered as responsible factor for the contamination besides poor quality fish handling (Hossain et al. 1999).

Presence of coliform and fecal coliform in studied fish indirectly indicated the contamination of water and also mishandling during processing and storage. $E$. coli is used as an indicator organism of contamination when present in small number or as an indicator of mishandling when appeared in large numbers (Silliker and Gabis 1976). In local market, fish can be contaminated as different fish are kept together and do not maintain hygiene, also seller use ice which are prepared by using contaminated water (Hossain et al. 1999). However, Salmonella spp. in aquaculture products mainly originated from the environment rather than poor standard of hygiene. This study reported more Salmonella spp. count in fish samples collected from culture source. Pathogenic strain of $E$. coli carry health risk to consumer and non-pathogenic strain E.coli carry alarming signals on fecal contamination (FSAI 2001). Salmonella spp. and Shigella spp. are highly pathogenic (Silliker and Gabis 1976, Hossain et al. 1999) and their presence in fish sample revealed that microbial quality of both captured and cultured fish were unacceptable. According to Geetha et al. (2014) E. coli and Salmonella spp. can survive for very long period of time in tropical water and once introduced may become adaptable to new conditions favoring the growth of microorganisms in the environment. So, proper care should be 
taken to avoid contamination of fish products during handling, processing and preservation.

The results of present study revealed that the presence of bacterial population in captured and cultured O. pabda were found to be higher than the acceptable standard limits by ICMSF, FSAI. So the required bacteriological quality of captured and cultured study fish was not satisfactory. Contaminated food is the source of food borne disease, therefore proper processing procedure and cooking methods of fish should be followed before consumption. It is recommended to ensure standard and quality production, good aquaculture practice, HACCP principles and good hygienic practices should be followed during fish production, handling, icing, post harvest processing and storage. However, more researches on microbial load in intestine of host fish are required to identify bacteria up to species level to understand the composition of fish gut microbiota and their roles in digestion.

\section{LITERATURE CITED}

AUSTIN, B. 2006. The bacterial microflora of fish, revised. Sci. World J. 6: 931-945.

BACTERIOLOGICAL ANALYTICAL MANUAL. 2018. U.S. Food and Drug Administration. https://www.fda.gov/food/laboratory-methodsfood/ bacteriologica-analytical-manual-bam.

BANIK, S., GOSWAMI, P., ACHARJEE, T. and MALLA, S. 2012. Ompok pabda (Hamilton-Buchanan, 1822): An endangered catfish of Tripura, India: reproductive physiology related to freshwater lotic environment. Journal of Environment 1(2): 45-55.

BEGUM, M., AHMED, A.T.A, DAS, M. and PARVEEN, S. 2010. Comparative microbiological assessment of five types of selected fishes collected from two different markets. Advances in Bio. Res. 4(5): 259-265.

BEGUM, M.K., CHOWDHURY, M.M., HAQUE, W. and NASRIN, T. 2015. Comparative microbiological assessment of export oriented fishes and locally marketed fishes of Bangladesh. IOSR J. of Phar. and Bio. Sciences 10(3 Ver. II): 17-23.

DEHLER, C.E., SECOMBES, C.J. and MARTIN, S.A.M. 2017. Environmental and physiological factors shape the gut microbiota of Atlantic salmon parr (Salmo salar L.). Aquaculture 467: 149157.

DoF. 2018. Yearbook of Fisheries Statistics of Bangladesh, 2017-18. Fisheries resources survey system (FRSS), Department of Fisheries. Bangladesh: Ministry of Fisheries and Livestock. 35: 129.

DUARTE, S., SILVA, F.C.D., ZAULI, D.A.G., NICOLI, J.R. and ARAÚJO, F.G. 2014. Gram-negative intestinal indigenous microbiota from two Siluriform fishes in a tropical reservoir. Braz. J. Microbiol. 45(3): 1283-1292.

ELHAM, I.A. 2017. Bacteriological study of fish samples collected from different markets in some egyptian governorates and antimicrobial sensitivity of isolates. Int. J. Curr. Microbiol. App. Sci. 6(5): 2765-2776.

EC (EUROPEAN COMMISSION). 2005. Microbiological Criteria for Foodstuffs. Regulation No. 2073/2005.

FAO (FOOD AND AGRICULTURAL ORGANIZATION). 1979. Manuals of food quality control: 4. microbiological analysis. FAO Food and Nutrition paper 14/4. 
FRANCOISE, L. 2010. Occurrence and role of lactic acid bacteria in seafood products. Food Microbiol. 27: $698-701$.

FSAI . 2001. Guidelines for the Interpretation of results of microbiological analysis of some ready-toeat foods sampled at point of sale . Online. Available at http://www.fsai.ie/service-contracts /guidance_notes/gn3.pdf. Accessed August 11, 2019.

GEETHA, S., SRI LAKSHMI, B., KARUNA, Y., RAO, V.G., KRISHNA, N.M., REDDY, N.R., BHAVANI, K. and BABU, K.R. 2014. Microbiological examination of three types of common edible marine fishes from Visakhapatnam fishing harbour, east coast of India. World J. of Fish and Mar. Sciences 6(5): 471-474.

HOSSAIN, M.M., UDDIN, M.N., ISLAM, M.N., CHAKRABORTY, S.C., and KAMAL, M. 1999. Study on the intestinal bacteria of Labeo rohita (Ham.) Bangladesh J. Fish. 3(1): 63-66.

ICMSF (INTERNATIONAL COMMISSION ON MICROBIOLOGICAL SPECIFICATION FOR FOODS). 1986. Microorganisms in foods : sampling for microbiological analysis: Principles and specific applications. Blackwell Scientific Publications 2(2): 197-202.

ISLAM, S. 2011. Brood rearing and induced breeding of fish (Ompok pabda) at BFRI, Mymensingh. M.Sc Thesis, Department of Aquaculture, Bangladesh Agricultural University, Mymensingh.

ISO (INTERNATIONAL STANDARD ORGANISATION). 1995. Recommendation of the meeting of the subcommittee, International Organization for Standardization, on meat and meat products. ISO/ TC-36/Sc-6. The Netherlands. 10-18.

IUCN Bangladesh. 2015. Red List of Bangladesh, Freshwater Fishes. IUCN, International Union for Conservation of Nature, Bangladesh country office, Dhaka, Bangladesh. 5: 3-359.

KOSTORI, F.A., PARWEEN, S. and ISLAM, M.N . 2011. Availability of small indigenous species (SIS) of fish in the Chalan Beel - the largest wetland of Bangladesh. Univ. J. Zool. Rajshahi Univ. 30: 67-72.

LEIVA, J.S., OPAZO, R., REMOND, C., URIBE, E., VELEZ, A. and ROMERO, J. 2017. Characterization of the intestinal microbiota of wild-caught and farmed fine flounder (Paralichthys adspersus). Lat. Am. J. Aquat. Res. 45(2): 370-378.

MAYA, R., DHEVENDARAN, K., ANNIE., M., GEORGEKUTTY, M.I. and NATARAJAN, P. 1995. Seasonal variation of bacteria in fish Etroplus suratensis and Etroplus maculatus (Pisces: Cichlidae). Indian J. Marine Sciences 24: 224-228.

NOOR, R., ACHARJEE, M., AHMED, T., DAS, K.K., PAUL, L., MUNSHI, S.K.,URMI, N.J., RAHMAN, F., and ALAM, M.Z. 2013. Microbiological study of major sea fish available in local markets of Dhaka city, Bangladesh. J. Microb. Biotech. Food Sci. 2(4): 2420-2430.

OKONKO, I.O., OGUNJOBI, A.A., FAJOBI, E.A., ONOJA, B.A., BABALOLA, E.T and ADEDEJI, A.O. 2008. Comparative studies and microbial risk assessment of different ready-to-eat (RTE) frozen sea-foods processed in Ijora-olopa, Lagos State, Nigeria. African Journal of Biotechnology. 7: 2898-2901.

PAL, M., KETEMA, A., ANBERBER, M., MULU, S. and DUTTA, Y. 2016. Microbial quality of fish and fish products. Beverage \& Food World 43(2): 46-49.

SILLIKER, J.H. and GABIS, D.A. 1976. KMSF method of studies VII indicator tests as substitutes for direct testing of dried foods and feeds for Salmonella. Can. J. Microbiol. 22: 971-974.

SNOWDON, J.A., CLIVER, D.O. and CONVERSE, J.C. 1989. Land disposal of mixed human and animal wastes: A review. Waste Managment Research 7: 121-134.

TUAN, T.N., DUC, P.M. and HATAI, K. 2013. Overview of the use of probiotics in aquaculture. Int. J. Fish. Aquac. 3(3): 89-97. 